\title{
Survey of Information Literacy Instructional Practices in U.S. Academic Libraries
}

\author{
Heidi Julien, Melissa Gross, and Don Latham
}

\begin{abstract}
An online survey sent to the community of professional librarians in the United States who provide information literacy instruction in academic libraries provided insights into their practices and the challenges they face. Data include current pedagogical methods, client groups of focus, assessment and evaluation, marketing, instructional objectives, incorporating the new Framework for Information Literacy for Higher Education into instruction, the role of technology in instruction, the importance of relationships with faculty and administrators, and a range of common challenges faced by instructional librarians. ${ }^{1}$ The survey results can help to identify best practices, to improve current practice, to compare practices across different contexts, and to inform preprofessional preparation of librarians who will become providers of instruction.
\end{abstract}

The instructional role continues to be emphasized in professional librarians' work in academic libraries. ${ }^{2}$ Even so-called "digital natives" do not enter postsecondary educational contexts with sophisticated information searching or information evaluation skills. ${ }^{3}$ Academic librarians, therefore, have significant responsibility to help students to become information-literate. This teaching role is complex and challenging, and it has shifted over time from a strict focus on teaching students how to find materials in the library to broader goals, which include teaching transferable skills such as critical thinking and information evaluation. This study reports a recent survey of U.S. professional librarians with instructional responsibilities that was conducted to explore respondents' views, practices, and concerns. The survey provided useful feedback on current pedagogical methods, client groups of focus, assessment and evaluation, marketing, instructional objectives, incorporating the new Framework for Information Literacy for Higher Education into instruction, the role of technology in instruction, the importance of relationships with faculty and administrators, and a range of common challenges faced by this community. ${ }^{4}$ This is the first comprehensive national survey of this type in the United States, although similar surveys have been conducted in other countries. ${ }^{5}$

Heidi Julien is Professor and Chair in the Department of Library and Information Studies at the State University of New York at Buffalo; e-mail: heidijul@buffalo.edu. Melissa Gross is Professor and Don Latham is Professor in the School of Information at Florida State University; e-mail: melissa.gross@cci.fsu.edu, don. latham@cci.fsu.edu. (C2018 Heidi Julien, Melissa Gross, and Don Latham, Attribution-NonCommercial (http://creativecommons.org/licenses/by-nc/4.0/) CC BY-NC. 
The definition of information literacy used in this study comes from the Association of College and Research Libraries:

Information literacy is the set of integrated abilities encompassing the reflective discovery of information, the understanding of how information is produced and valued, and the use of information in creating new knowledge and participating ethically in communities of learning. ${ }^{6}$

We were also interested in the extent to which the Framework for Information Literacy for Higher Education is being used by instructional librarians. The Framework operationalizes the ACRL definition of information literacy by focusing on seven threshold concepts and related knowledge practices and dispositions. The threshold concepts that constitute the Framework are:

- Authority Is Constructed and Contextual

- Information Creation as a Process

- Information Has Value

- Research as Inquiry

- Scholarship as Conversation

- $\quad$ Searching as Strategic Exploration ${ }^{7}$

The survey data are useful to identify best practices, to identify opportunities for improvement to current practice, to compare practices across different contexts, and to inform preprofessional preparation of librarians who will become providers of instruction. Previous evidence suggests room for improvement in the preparation of librarians for this role. ${ }^{8}$ In addition, the survey results are directly comparable to several previous surveys conducted in Canada, which allow for future comparative analysis. ${ }^{9}$

\section{Research Questions}

The following questions motivated this study:

1. What are the instructional practices of librarians with responsibility for information literacy instruction in academic libraries in the United States?

2. What are the challenges faced by these librarians in their instructional roles?

3. What are some of the opportunities for improvement in information literacy instruction practice?

\section{Methods}

Data were collected via an online national survey. The survey asked respondents for demographic data to identify the context in which they worked. These data points included the kind of library they worked in, the size of their undergraduate population, and their job title. The main body of the survey focused on instruction practices, issues surrounding information literacy, and assessment of instruction. Concerning instruction practices, the survey asked: whether respondents focus their instruction on any particular discipline, whether their library offers any formal or informal instruction, whether they articulate written objectives for their instruction, which staff take responsibility for instruction, what proportion of staff time is spent on instruction, what proportion of the student population receives information literacy instruction, the content and methods of instruction, the client groups of focus, the effect of changes in information technology on instructional methods and content, and current and ideal instructional objectives (and whether these have changed). Issues of information literacy were explored in questions that asked: what constitutes information literacy, who should take responsibility for developing information literacy skills in students, and to what extent is instruction informed by the ACRL Framework. ${ }^{10}$ The survey also 
asked questions about the quality of instruction and how it is assessed. This part of the survey collected respondents' opinions on whether instruction is meeting objectives and asked about methods of assessing student learning, methods of evaluating instruction, financial and nonfinancial support for instructional work, marketing of instruction, and challenges to instruction. The survey is provided in appendix B.

The survey instrument was designed in English using SelectSurvey and was intended to take no more than 20 minutes to complete. General feedback on the survey design and item responses was solicited from two professional librarians with instructional responsibilities at two geographically disparate universities. Their feedback was useful to ensure that the survey reflected current terminology and practice. Participants were recruited from the ILI-L listserv, an American Library Association (ALA) listserv that focuses on information literacy instruction. At the time of the survey, the listserv had approximately 6,000 subscribers. These subscribers are typically professional librarians and paraprofessional library workers who have an interest in information literacy. The introduction to the survey specified that professional academic librarians (that is, those employed in university or college libraries) who had responsibilities for information literacy instruction were the target sample (see appendix A). Therefore, any librarians or paraprofessionals on the listserv who were employed in other types of libraries (such as public libraries) were not invited to respond. Consent to participate in the survey was implied by completion of the survey. Prior to participant recruitment and data collection, ethics approval for the study was obtained at the universities where the authors are employed.

In spring 2016, the survey invitation was posted to the ILI-L listserv. The survey remained open for six weeks, with reminders sent out after two weeks, after four weeks, and one week prior to closing. SelectSurvey provided basic quantitative analyses of data, and responses to open-ended items were analyzed using a qualitative content analysis method. ${ }^{11}$

\section{Results}

\section{Respondents}

The total number of respondents was 622, although the number of respondents per survey question varied. Since the size of the population is unknown, this is not a probability sample. The largest proportion $(60 \%, n=227)$ of respondents work in universities, while 39 percent $(n=148)$ work in colleges or technical institutes. The largest

\begin{tabular}{|c|c|c|}
\hline \multicolumn{3}{|c|}{$\begin{array}{c}\text { TABLE } 1 \\
\text { Respondents' Workplace }\end{array}$} \\
\hline Your library is associated with a: & Frequency & Percent \\
\hline College or Technical Institute & 148 & 39 \\
\hline University & 227 & 60 \\
\hline Other & 6 & 2 \\
\hline Total & 381 & $101 *$ \\
\hline Size of Undergraduate Population & Frequency & Percent \\
\hline Fewer than 10,000 & 237 & 62 \\
\hline $10,000-20,000$ & 88 & 23 \\
\hline More than 20,000 & 57 & 15 \\
\hline Total & 382 & 100 \\
\hline
\end{tabular}


proportion $(62 \%, \mathrm{n}=237)$ work in institutions with fewer than 10,000 undergraduate students; 23 percent $(n=88)$ work in institutions with 10,000 to 20,000 students, and 15 percent $(n=57)$ work at institutions with more than 20,000 students. These data are summarized in table 1 above.

Forty-nine percent $(n=185)$ of respondents who provided their job title had "information literacy," "instruction," or a similar concept as part of their job title. Examples of other job titles submitted include "assistant librarian," "social sciences librarian," "head of public services," and "associate professor." Only 92 participants indicated that their library focuses on a particular discipline or subject area. The largest proportion $(73 \%, \mathrm{n}=67)$ focus on a wide range of disciplines or a mixture of disciplines, while 16 percent $(n=15)$ focus on health-related disciplines, and 11 percent $(n=10)$ focus on humanities/social sciences or liberal arts. Thus, the data indicate that most respondents worked in libraries with general academic collections.

When asked who had primary responsibility for instruction (and allowed to "check all that apply"), the majority of respondents put reference/public service librarians at the top of the list, with 63 percent of all responses $(n=226)$. Full-time instructional librarians were also seen as responsible for instruction, receiving 55 percent of all responses $(n=196)$, and other librarians were also considered to carry responsibility for instruction by 101 respondents (28\%). Staff other than full-time instructional librarians were seen as carrying primary responsibility for instruction by 43 respondents (12\% of responses).

\begin{tabular}{|c|c|c|}
\hline \multicolumn{3}{|l|}{$\begin{array}{c}\text { TABLE } 2 \\
\text { Instruction Staffing }\end{array}$} \\
\hline Primary Responsibility for Instruction & Frequency & Percent \\
\hline Full-time instruction librarian & 196 & 55 \\
\hline Reference/public service librarians & 226 & 63 \\
\hline Other librarians on staff & 101 & 28 \\
\hline Other staff, please specify & 43 & 12 \\
\hline Total & 381 & $158^{*}$ \\
\hline Staff Time on Instruction (non-full-time staff; start of term) & Frequency & Percent \\
\hline $0-25 \%$ & 137 & 41 \\
\hline $26-50 \%$ & 123 & 37 \\
\hline $51-75 \%$ & 66 & 20 \\
\hline More than $75 \%$ & 10 & 3 \\
\hline Total & 336 & $101 * *$ \\
\hline Staff Time on Instruction (non-full-time staff; rest of year) & Frequency & Percent \\
\hline $0-25 \%$ & 199 & 59 \\
\hline $26-50 \%$ & 107 & 32 \\
\hline $51-75 \%$ & 30 & 9 \\
\hline More than $75 \%$ & 0 & 0.0 \\
\hline Total & 336 & 100 \\
\hline $\begin{array}{l}\text { *Total exceeds } 100 \text { because respondents could choose more tha } \\
* * \text { Total exceeds } 100 \text { due to rounding }\end{array}$ & one answer. & \\
\hline
\end{tabular}




\section{Instructional Practices}

In terms of time spent on instruction by staff other than full-time instructional staff, the survey differentiated between time spent at the start of academic terms versus the rest of the year. Respondents estimated that staff spend significant time on instruction at the start of the academic term. Of the total respondents, 137 (41\%) said staff spend up to 25 percent of their time on instruction, 123 (37\%) said staff spend 26 to 50 percent of their time on instruction, $66(20 \%)$ said staff spend 51 to 75 percent of their time on instruction, and $10(3 \%)$ said staff spend more than 75 percent of their time on instruction. In contrast, respondents estimated that, during the remainder of the academic year, non-full-time instructional staff continue to spend time on instruction. Among respondents 199 (59\%) said staff spend up to 25 percent of their time on instruction, 107 (32\%) said staff spend 26 to 50 percent of their time on instruction, and $30(9 \%)$ estimated staff spend 51 to 75 percent of their time on instruction. None of the respondents estimated that staff spend more than 75 percent of their time on instruction during the remainder of the academic year. These data are displayed in table 2 below.

Most respondents reported that teaching information literacy is a shared responsibility with teaching faculty and with the students themselves (see table 3).

\begin{tabular}{|l|c|c|}
\hline \multicolumn{3}{|c|}{ TABLE 3 } \\
\multicolumn{2}{|c|}{$\begin{array}{l}\text { Respondents' Views on Academic Librarians' Level of Responsibility for } \\
\text { Various Aspects of Information Literacy }\end{array}$} \\
\hline \multicolumn{1}{|c|}{ Recognizing when information is needed: } & Frequency & Percent** \\
\hline Not responsible & 15 & 6 \\
\hline Partially responsible & 114 & 45 \\
\hline Fully responsible and transmitted: & 25 & 10 \\
\hline Understanding how information is generated, organized, & Frequency & Percent* \\
\hline Not responsible information issues: & 2 & 1 \\
\hline Partially responsible & 99 & 39 \\
\hline Fully responsible & 98 & 9 \\
\hline Understanding some ethical, legal, economic, and sociopolitical & Frequency & Percent* \\
\hline Not responsible & & \\
\hline Partially responsible & 2 & 1 \\
\hline Fully responsible & 131 & 53 \\
\hline Understanding that there exists a wide variety of information & Frequency & Percent** \\
\hline sources beyond the obvious: & & \\
\hline Not responsible & 1 & 0 \\
\hline Partially responsible & 105 & 42 \\
\hline Fully responsible & 84 & 33 \\
\hline Understanding how to locate efficiently and effectively & Frequency & Percent* \\
\hline Not responsible & & \\
\hline Partially responsible & 0 & 0 \\
\hline Fully responsible & 65 & 26 \\
\hline & 151 & 60 \\
\hline
\end{tabular}




\begin{tabular}{|c|c|c|}
\hline \multicolumn{3}{|c|}{$\begin{array}{c}\text { TABLE } 3 \\
\text { Respondents' Views on Academic Librarians' Level of Responsibility for } \\
\text { Various Aspects of Information Literacy }\end{array}$} \\
\hline $\begin{array}{l}\text { Understanding how to use efficiently and effectively } \\
\text { information from many sources: }\end{array}$ & Frequency & Percent* \\
\hline Not responsible & 2 & 1 \\
\hline Partially responsible & 113 & 46 \\
\hline Fully responsible & 62 & 25 \\
\hline Understanding how to critically analyze and evaluate information: & Frequency & Percent* \\
\hline Not responsible & 0 & 0 \\
\hline Partially responsible & 130 & 52 \\
\hline Fully responsible & 39 & 20 \\
\hline Knowing how to think critically in general: & Frequency & Percent* \\
\hline Not responsible & 22 & 9 \\
\hline Partially responsible & 139 & 55 \\
\hline Fully responsible & 9 & 4 \\
\hline
\end{tabular}

First-year students are the focus of 85 percent $(n=292)$ of respondents, and 81 percent $(n=277)$ of respondents focus on undergraduates in particular disciplines. Only 24 percent $(n=81)$ of respondents offer instruction to teaching faculty. The largest proportion of respondents $(34 \%, n=110)$ estimated that they reach 50 to 75 percent of their undergraduates with their instruction; 28 percent $(n=93)$ reach fewer than 25 percent of their undergraduates, and 23 percent $(n=76)$ reach 76 to 100 percent of their undergraduates. The vast majority $(92 \%, n=349)$ offer formal instructional opportunities in their libraries (that is, scheduled in advance). Participants who work in libraries that do not offer formal instruction provided reasons such as: "partly size of library staff, but mainly a[n]... unconscious belief that information literacy will just happen as part of the regular course work," and "the culture at this institution hasn't been favorable for including librarians and information literacy skills as part of the curriculum, but we are in the process of negotiating new partnerships and opportunities to develop a program." Nearly all respondents $(99 \%, \mathrm{n}=358)$ offer informal instruction, but only 52 percent $(n=179)$ have a written statement of objectives for their instruction. The most widely reported foci for instruction are databases $(94 \%, n=322)$, search strategies $(88 \%, n=301)$, library use in general $(84 \%, n=287)$, and the online catalog $(77 \%, n=$ 264). The data on instruction foci are provided in table 4 below.

Respondents primarily use hands-on instruction in a computer lab $(87 \%, \mathrm{n}=299)$ and one-on-one instruction $(87 \%, \mathrm{n}=298)$, lectures/demonstrations in subject classrooms $(81 \%, \mathrm{n}=277)$, and web-based subject guides $(73 \%, \mathrm{n}=252)$ as their instructional methods. The data on methods of instruction are provided in table 5 below.

Respondents noted that technology has affected instructional delivery and content in the past few years; 61 percent $(n=194)$ believe that IT has affected instructional delivery "quite a bit" or "a great deal." Fewer believe that IT has affected content: 49 percent $(\mathrm{n}=153)$ report that instructional content has been affected "quite a bit" or "a great deal." Forty-five percent $(n=141)$ of respondents believe that use of IT has improved students' interest or participation in instructional opportunities for 45 percent $(\mathrm{n}=$ 


\begin{tabular}{|l|c|c|}
\hline \multicolumn{3}{|c|}{ TABLE 4 } \\
Instruction Topics \\
\hline Topics & Frequency & Percent \\
\hline Print indexes or abstracts & 21 & 6 \\
\hline Audiovisual materials & 51 & 15 \\
\hline CD-ROM resources & 1 & 0 \\
\hline Government documents & 52 & 15 \\
\hline Library classification system & 103 & 30 \\
\hline Online databases & 322 & 94 \\
\hline Bibliographic management tools & 174 & 51 \\
\hline Open access resources & 93 & 27 \\
\hline Other print reference materials & 111 & 32 \\
\hline Catalog/OPAC & 264 & 77 \\
\hline Internet/World Wide Web & 230 & 67 \\
\hline Library use in general & 287 & 84 \\
\hline Electronic documents & 128 & 37 \\
\hline Search strategies (such as Boolean) & 301 & 88 \\
\hline Citation metrics & 95 & 28 \\
\hline Other & 53 & 15 \\
\hline & $\mathbf{3 4 3}$ & \\
\hline Total Respondents & & \\
\hline
\end{tabular}

141) of respondents, while 19 percent $(n=55)$ disagree. Those who reported positive changes indicated that using IT increases student engagement, connects with tech-savvy students, provides instructors with the ability to immediately support assignments, and helps instructional librarians to provide content that is more active, fun, personal, and relevant to students' daily lives. One respondent stated that "we have included practical examples that incorporate technology that students are already familiar with and allow them to use it-incorporating their mobile technology as an assessment aid, for instance." Another wrote "to be honest, our students have indicated that they feel like we are less old-fashioned and less boring this way." Another respondent stated, "[technology] allows students to independently organize their learning experience in a manner that suits their personal style. It provides a more active experience for students and creates a more student-focused environment." Another commented, "I think students are aware of how much information technology is impacting their professions/discipline, and so are motivated to engage with it now, as students, as they see it as a key competency and a competitive skill." However, another respondent warned:

I would say that IT has increased somewhat interest and participation, but I don't think that it is a silver bullet that can cover up a poorly designed or prepared instruction, or a class with little space for active learning. I also don't think that technology has the 'wow factor' it once did and it is more or less an expectation of students.

Most respondents $(64 \%, \mathrm{n}=182)$ also reported that using IT has improved instruction. One commenter noted, "[P]edagogically, I employ constructivist theories to my practice. Because of this, I believe that linking academic skills that I am teaching to non-academic skills or experiences with which students are familiar can help make headway to true learning. The way I can do that is through use of the [I]nternet and digital technologies which students employ in their real lives." Another noted, "[T] q quote the framework, scholarship/research becomes more of a conversation than a lecture." One wrote, "I think the various technologies allow us to reach students with varied learning styles and varied levels of accessibility." Another stated, "I think that creatively designing instruction sessions that leverage the technology - allow students to learn and discover 


\begin{tabular}{|c|c|c|}
\hline \multicolumn{3}{|c|}{$\begin{array}{c}\text { TABLE } 5 \\
\text { Methods of Instruction }\end{array}$} \\
\hline Methods & Frequency & Percent \\
\hline Web tutorials & 177 & 52 \\
\hline Hands-on instruction in computer lab & 299 & 87 \\
\hline Individualized instruction (one-on-one) & 298 & 87 \\
\hline Courseware & 49 & 14 \\
\hline Video recordings (such as YouTube videos) & 182 & 53 \\
\hline Self-paced library tours & 42 & 12 \\
\hline Workbook program & 4 & 1 \\
\hline Lectures/demonstrations in subject classes & 277 & 81 \\
\hline Essay assistance (workshops) & 66 & 20 \\
\hline Additions to course notes for distance students & 30 & 9 \\
\hline Group instruction courses/subjects in the library & 207 & 60 \\
\hline Social media & 48 & 14 \\
\hline Flipped classrooms & 94 & 27 \\
\hline Embedded librarians & 143 & 42 \\
\hline Credit course & 78 & 23 \\
\hline Noncredit course & 26 & 8 \\
\hline Posters & 20 & 6 \\
\hline Group library tours & 112 & 33 \\
\hline Library guides/handouts web format & 175 & 51 \\
\hline Library guides/handouts paper format & 72 & 21 \\
\hline Other & 17 & 5 \\
\hline Total Respondents & 343 & \\
\hline
\end{tabular}

things on their own and share that knowledge with others has improved the learning experience for students and librarians."

Respondents reported that their primary instructional objective is to teach students how to critically evaluate the quality and usefulness of information, followed by teaching general research strategies. When asked to rank their instructional objectives, participants gave the highest ranking to "teach students how to critically evaluate the quality and usefulness of information" (2.36). The second highest ranking was "teach students general research strategies" (2.48). The rank order of instructional objectives was mirrored in participants' preferred instructional objectives. Some respondents indicated they had additional instructional objectives but did not rank these as important. A complete list of items and rankings is presented in table 6 below.

Responses to other survey items reveal that slightly fewer than half $(49 \%, n=121)$ believe that they are meeting their current instructional objectives, 29 percent $(n=71)$ do not believe they are meeting these objectives, and 23 percent $(n=57)$ do not know. Student learning is assessed primarily through faculty feedback $(58 \%, \mathrm{n}=152)$, formative assessment during in-class sessions $(41 \%, n=107)$, and student self-assessment $(40 \%, n=104)$.

Evaluation of the library's instructional program is equally informal: 59 percent (n $=154)$ do so through informal faculty feedback, 53 percent $(n=139)$ do so through 


\begin{tabular}{|c|c|}
\hline \multicolumn{2}{|l|}{$\begin{array}{c}\text { TABLE } 6 \\
\text { Instructional Objectives }\end{array}$} \\
\hline Objectives (ranked from 1 , most important, to 6, least important) & Ranking Average \\
\hline Teach to critically evaluate the quality and usefulness of information & 2.36 \\
\hline Teach students general research strategies & 2.48 \\
\hline Teach students how to find information in various sources & 2.64 \\
\hline Teach students how to locate materials in the library & 4.10 \\
\hline Teach students how databases in general are structured & 4.38 \\
\hline Teach students how to manage information & 5.03 \\
\hline Teach awareness of technological innovations & 5.99 \\
\hline Other, please state and include ranking & 4.36 \\
\hline Total Respondents & 273 \\
\hline
\end{tabular}

informal student feedback, and 44 percent $(n=115)$ via self-assessment by the librarians themselves. Fourteen percent $(n=35)$ reported that they do no evaluation. Publicity is also relatively informal: 89 percent $(n=234)$ use personal faculty contact, 71 percent $(n=187)$ use notices or letters to faculty, and 54 percent $(n=143)$ publicize instruction at departmental meetings.

Respondents also noted that their instruction is only partly informed by the new Framework for Information Literacy for Higher Education. ${ }^{12}$ The largest proportion of respondents $(41 \%, \mathrm{n}=103)$ report that the Framework has had no influence or only a minor influence on their practice, while 31 percent $(n=78)$ indicated that it has had a significant influence. Most respondents feel fully or partly supported by their library administrations for their instructional work $(79 \%, n=194)$, but only 6 percent $(n=16)$ have budgeted funds for instruction.

\section{Challenges}

A wide range of challenges to instruction were reported, but a few significant themes emerged. Some of the challenges identified in the open-ended responses are connected with lack of time and lack of adequate staffing:

- Time: 1) to get into the classes, 2) to prep the classes, 3) scheduling all the instruction sessions, frequently they happen in a small period of time, making a couple of weeks really crazy.

- A staff that is stretched thinly already and is covering more than one position. Lack of time for planning and strategizing.

- Balancing instruction with other job duties, lack of formal training (no instruction courses or student teaching opportunities provided in MLS program), shortage of available instruction space and technology during peak demand weeks in the year.

- Too many students, too few librarians.

- The prevalence of the one-shot model of library instruction and the expectation that what we have to teach can be communicated over the course of an hour.

- We are at saturation level, presently, and cannot expand our program any more. We focus on instruction for full-sized classes in the English department and for all students on a 1:1 student basis.

Other challenges relate to lack of student motivation:

- Students who don't realize they don't have researching skills.

- My library focuses only on freshmen and sophomores. We may see some of the 
same students a few times in any given semester and it's clear that they become bored with library instruction sessions and think each session contains the same content even though - from our perspective-we tailor each instruction session to the course subject and research assignment. I want to make our instruction sessions more engaging with a greater focus on the information literacy Framework concepts through activities and gamification techniques. I want students to leave with a greater understanding of how information works and develop transferrable skills that they can use beyond the classroom.

- Student motivation/attention/engagement and same for non-librarian faculty. Several other respondents echoed the inconsistency of buy-in from nonlibrarian faculty:

- Faculty investment-we have a mandated set of classes that need to provide library instruction, and faculty buy-in varies greatly.

- Faculty indifference. Getting the word out to a large contingent of adjunct faculty.

- Getting faculty to understand the value of instruction. Because librarians don't have the standing or cultural value that faculty do, librarians give tours not instruction in the faculty view.

- Not enough faculty interest in library instruction. No formal assessment program, so no proof that library instruction is helping improve student work.

Perhaps most vexing is a perceived lack of support from administration:

- Revolving administration who have bigger issues to deal with.

- We have no scaffolding to instruction. I may teach an introductory English class and an upper-division political science class in the same day, and do very similar things. I can't be sure that the upper division students definitely got basic instruction in lower-level classes. I'd rather spend time showing them how to use advanced government information or demographics or data sets, but sometimes they don't know how to search a library database. We can do more towards scaffolding, but it requires a bigger institutional push that we currently don't have.

- Our administration-despite claiming advocacy for library instruction-has no fundamental understanding of information literacy instruction. We are moving toward a performance based model across all disciplines and without a credit library course, we are unable to provide metrics that demonstrate our value (quantitatively).

- Little support from the administration and very little support from the curriculum. Our success depends on individual faculty members who see information literacy as an important component of liberal arts education. No support for assessment means that there's no motivation or time for us to evaluate students' skills as a whole to propose any changes.

- Lack of administrative support; dean and his minions do not think what we do in library instruction sessions has much value-his focus is on 3D printers and virtual reality games.

Respondents were given an opportunity to make final open-ended comments, and some are particularly revealing. While some indicated significant problems (one described the situation as a "train-wreck"), others were more optimistic. Here are some examples:

- There is hope and change is happening. I have a few faculty on my side and a plan for incorporating information fluency more intentionally into the curriculum. Interest is growing and faculty are realizing that we can work together to improve learning outcomes. 
- I became an Academic Librarian to teach. With the addition of the Framework for Information Literacy, I have fully evolved my library instruction with tremendous success. Teaching \& Learning Services within my libraries have raised our instructional brand in a significant way.

- I am lucky to be in an environment where faculty truly see me as a partner, both inside and outside the classroom.

- Currently in the process of developing a new information literacy plan and program where research skills are the beginning and reflective of the ACRL Standards. After research skills, the research process is the focus-faculty and librarians collaborate on curriculum and assignments in order to incorporate the ACRL Framework in disciplines. (Wish us luck!)

- We are improving in the teaching and assessment of student learning outcomes but have a long way to go. The IL Standards were great as training wheels to get us moving in the right direction towards authentic assessment, but the IL Framework will truly set us free. Re-imagining what we can do with the reference desk will also be a piece of the puzzle as will partnering more closely with the writing center.

\section{Discussion}

\section{Opportunities for Improvement}

These data demonstrate significant commitment to information literacy instruction, as well as a host of substantial challenges to success. The data also suggest multiple opportunities for improvement in instructional practice. In particular, fewer than half of respondents articulate written objectives for the instruction. The practice of recording instructional objectives is a key step in assessing instructional outcomes and evaluating instructional effectiveness. Thus, consistent with that finding, the survey also revealed that assessment and evaluation remain largely informal. In the absence of systematic assessment of learning outcomes associated with information literacy instruction, the return on investment in instructional work is uncertain, and administrators may have difficulty supporting instructional work. In addition, marketing of instructional opportunities remains relatively informal, suggesting an area that might be strengthened. The picture of instructional practices of librarians responsible for information literacy instruction in the United States that emerges from the data is one in which undergraduate students are the main target population, and this audience is reached mainly through formal, but also informal, instructional opportunities in libraries. However, only about half of libraries have formal objectives for instruction, which may hamper their ability to fully assess programs or to have the data at hand to demonstrate the impact the library has in ensuring that students reach competency in information literacy. The focus of much instruction is the use of databases, search strategies, general library use, and use of the online catalog. While these topics reflect needed skills, they also represent the mainstay of instructional efforts. While some respondents report including topics such as social media, open access publishing, images and fair use, and citation metrics, most instruction is skills-based and, though increasingly integrating information technology, has yet to incorporate the threshold concepts outlined in the Framework for Information Literacy for Higher Education..$^{13}$ This may in large part be due to the newness of the Framework; thus, changes in practice may not have had time to be fully implemented. It is exciting to see that the vast majority of respondents see connections between the concepts presented in the Framework and their responsibility to raise the level of information literacy among students.

In assessing student learning and evaluating the effectiveness of instruction, librarians are using a variety of strategies, but the main data sources for these evaluations 
lean heavily on student self-assessments and faculty feedback to gauge student learning and self-evaluation and informal feedback from faculty and students when assessing the quality of the instruction program. Among respondents in this study, assessing the quality of instruction and programs are topics that academic librarians continue to struggle with.

The challenges faced by these librarians are many. The main issues are time and insufficient support. Respondents talk about being spread thin in terms of their ability to cover the number of classes necessary to meet the needs of the student body. Even though they are stretched thin, librarians are frustrated by the view that information literacy can be achieved over the course of a one-hour demonstration and want to see more support and a greater visibility as instructors who have a high level of needed expertise. Recognition and support are needed from administrators and nonlibrarians, and academic librarians continue to work to educate these stakeholders in the importance of information literacy and the usefulness of instructional partnerships with librarians. Several respondents had stories of success to share.

\section{Comparison with Canadian Data}

The survey findings are largely echoed in data from Canadian surveys of information literacy instruction in academic libraries over an extended period of time. ${ }^{14}$ While the Canadian surveys were distributed differently (sent directly to institutions rather than to a listserv for response by any academic librarian), the instrument used was identical (with small updates to reflect current terminology, and a shift from paper to online distribution over time), so data are roughly analogous. In addition, it must be noted that the last Canadian survey was conducted five years ago, and some changes in practice may have occurred since that time. There are few significant differences in results between the U.S. and the latest Canadian data, but one difference is a much larger proportion of librarians in the U.S. sample whose primary job responsibility is information literacy instruction; according to the last Canadian survey, primary responsibility for information literacy instruction is shared across multiple reference librarians. This difference could be due to the passage of time (that is to say, there may now be more dedicated instructional librarians in Canada). The survey results regarding informal assessment and evaluation are similar in the Canadian data. However, written statements of teaching objectives were even less common in Canadian academic libraries. Thus, some of the biggest opportunities to improve instruction are evident in both countries. Finally, respondents in the U.S. and Canadian data sets reflect identical issues and concerns, including variable buy-in from students and course instructors, as well as from library administrations.

\section{Implications for Preprofessional Preparation}

Through this survey, the practice community has provided data with significant potential to inform the preparation of librarians for instructional work. First, understanding the basic who, what, and where of instruction can assist preprofessionals to understand the scope of daily practice. Areas where opportunities for improvement to practice exist (such as formalizing assessment of student learning and evaluation of instructional programs, developing marketing expertise, and identifying opportunities for pedagogical innovation) can also inform course content decisions made by educators in preprofessional programs. Understanding the ongoing challenges faced by instructional librarians, which appear to be rather enduring, can also open opportunities for discussion and strategic thinking among preprofessional librarians about ways to ameliorate barriers to achieving the full potential of information literacy instruction. ${ }^{15}$ 


\section{Future Research}

As has been done with the survey data gathered in Canada, this survey, or a version of it, could be conducted periodically over time to provide longitudinal data. Analyzing trends can help to demonstrate progress, as well as identify ongoing and persistent challenges that may merit particular focus for amelioration. More in-depth exploration of instructional work through focus groups and interviews, for example, could also enrich these survey data. There are good examples of such studies that could be used as models. ${ }^{16}$

\section{Conclusion}

Information literacy instruction is a fundamental professional practice in academic libraries, and academic librarians are primary providers of information literacy instruction generally. Improvements to that practice are possible only when current practices across the field are understood. Before this survey, there were no published descriptive data on those instructional practices for the United States as a whole, a gap that this study sought to fill. As information literacy is widely understood to provide a critical foundation for success in daily life, the workplace, and in civic engagement, it is important to promote best practices for information literacy instruction. The data gathered in this study have the potential to be foundational for identifying and promoting those best practices.

\section{Acknowledgements}

The authors are grateful to the librarians who helped pretest the survey and those who took the time to share their experiences and insights by responding to the survey. 


\section{Appendix A. Invitation to Participate in the Survey}

\section{Survey of Information Literacy Instruction in U.S. Academic Libraries}

Are you an academic librarian with instructional responsibilities? You are invited to participate in an online survey aimed at U.S. academic librarians. The purpose of the survey is to identify information literacy instruction practices in U.S. academic libraries. The research is being done by Dr. Heidi Julien from the University at Buffalo and Dr. Don Latham and Dr. Melissa Gross from Florida State University.

The survey should take no more than 20 minutes to complete, and is accessible using this link: [link here].

The survey is voluntary. You have the right to not participate in this study, and you have the right not to respond to any particular question items on the survey. If the survey is completed and submitted, your consent to participate will be assumed. Once your survey responses are submitted, you will not be able to withdraw from the study. The survey does not collect identifying information, so survey respondents are anonymous. The survey data will be handled in compliance with standard ethical principles. The study has been approved by the University at Buffalo Institutional Review Board and the Florida State University Institutional Review Board. The data will be used to write research papers and make conference presentations. As far as is known, there are no particular benefits to you to participate in this study, nor is there any potential harm. The only inconvenience to you is your time. If you participate, your survey responses will be stored in a safe place until the study is completed and the results are disseminated (computer data will be password protected); then they will be deleted.

If you have any questions about this study, now or in the future, please contact:

Dr. Heidi Julien

Department of Library and Information Studies

State University of New York at Buffalo

heidijul@buffalo.edu 716-645-1474

You can also contact the research participant advocate at 716-888-4845 or researchadvocate@buffalo.edu. 


\section{Appendix B. Survey of Information Literacy Instruction Practices in U.S. Academic Libraries}

Welcome,

Are you an academic librarian with instructional responsibilities? You are invited to participate in an online survey aimed at U.S. academic librarians with instructional responsibilities. The purpose of the survey is to identify information literacy instruction practices in U.S. academic libraries.

\begin{tabular}{|c|c|}
\hline 1. & $\begin{array}{l}\text { Your library is associated with a: } \\
\text { College or technical institute } \\
\text { University } \\
\text { Other, please specify: }\end{array}$ \\
\hline 2. & $\begin{array}{l}\text { What is the size of the undergraduate student population at your institution? } \\
\text { Fewer than } 10,000 \\
10,000-20,000 \\
\text { More than } 20,000\end{array}$ \\
\hline 3. & What is your job title? \\
\hline 4. & If your library focuses on a particular discipline(s) or subject area(s), please indicate: \\
\hline 5. & $\begin{array}{l}\text { Does your college or university library offer formal (i.e., scheduled in advance) } \\
\text { instructional classes? } \\
\text { Yes } O \text { No }\end{array}$ \\
\hline 6. & $\begin{array}{l}\text { Please indicate briefly why you think there is no formal instructional program at your } \\
\text { library. }\end{array}$ \\
\hline 7. & $\begin{array}{l}\text { Do you have a written statement of the objectives of your instructional program? } \\
\text { Y Yes } \bigcirc \text { No }\end{array}$ \\
\hline 8. & $\begin{array}{l}\text { Does your library routinely provide informal instruction (i.e., one-to-one, ad hoc } \\
\text { instruction) via subject guides (online and/or paper), online tutorials, point-of-use } \\
\text { instruction, etc.? } \\
\text { Yes } \bigcirc \text { No }\end{array}$ \\
\hline 9. & $\begin{array}{l}\text { Who is primarily responsible for instruction in your library? (check all that apply) } \\
\text { Full-time instruction librarian(s) } \\
\text { Reference/public service librarians } \\
\text { Other librarians on staff } \\
\text { Other staff, please specify: }\end{array}$ \\
\hline 10. & $\begin{array}{l}\text { Please estimate the proportion of staff time spent on instruction at the start of } \\
\text { academic terms, for those staff involved in instruction (other than full-time } \\
\text { instruction staff). } \\
0 \%-25 \% \\
26 \%-50 \% \\
51 \%-75 \% \\
\text { More than } 75 \%\end{array}$ \\
\hline 11. & $\begin{array}{l}\text { Please estimate the proportion of staff time spent on instruction during the remainder } \\
\text { of the academic year, for those staff involved in instruction (other than full-time } \\
\text { instruction staff). } \\
0 \%-25 \% \\
26 \%-50 \% \\
51 \%-75 \% \\
\text { More than } 75 \%\end{array}$ \\
\hline
\end{tabular}


12. For which of the following do you commonly provide instruction? (Check all that apply)

Print indexes or abstracts

Audiovisual materials

O CD-ROM resources

O Government documents

Library classification system

Online databases

O Bibliographic management tools

Scholarly communication (e.g., open access publishing or open education resources)

Other print reference materials

Catalog/OPAC

The Internet/World Wide Web

Library use in general

Electronic documents

Search strategies (e.g., Boolean)

Citation metrics

Other, please specify

13. Which of the following methods do you use in your instruction? (check all that apply)

Web tutorials

Hands-on instruction in computer lab

Individualized instruction (one-on-one)

O Courseware

Video recordings (e.g., YouTube videos)

Self-paced library tours

Workbook program

Lectures/demonstrations in subject classes

Essay assistance (workshops)

Additions to course notes for distance students

Group instruction focused on particular courses or subjects [in the library]

Social media

Flipped classrooms

E Embedded librarians

Credit course

Noncredit course

P Posters

Group library tours

Library guides or handbooks, web format

Library guides or handbooks, paper format

Pathfinders or subject guides (e.g., LibGuides), web format

Pathfinders or subject guides, paper format

$\bigcirc$ Other, please specify

14. On what group(s) does your instructional program focus? (Check all that apply)

First-year students

Undergraduates in certain subject disciplines

Teaching staff (faculty)

Transfer students

$\bigcirc$ Adult re-entry students

Postgraduate students

General community

Other, please specify 
15. Overall, what proportion of undergraduate students do you estimate that you reach in your instructional program?

○ $76 \%-100 \%$

O $50 \%-75 \%$

Fewer than $50 \%$

Not able to determine

Other, please explain

16. How much has information technology changed the way you deliver instruction in the last few years?

Not at all

Only slightly

Q Quite a bit

A great deal

17. If information technology has changed the way you deliver instruction, can you give an example?

18. How much has information technology affected the content of your instruction in the last few years?

Not at all

Only slightly

Quite a bit

A great deal

19. If information technology has changed the content of your instruction, can you give an example?

20. If information technology has changed either the delivery or content of your instruction, do you think that these changes have increased students' interest or participation in instruction?

○ Yes

O No

$\bigcirc$ Don't know

21. Please explain briefly how you think these changes have increased students' interest or participation.

22. If information technology has changed either the delivery or content of your instruction, do you think that these changes have improved instruction?

O Yes

O No

$\bigcirc$ Don't know

23. If yes, please indicate "how" technology has improved instruction.

24. What are the objectives (explicitly written or not) of your current instruction?

Please rank from 1 (most important) to 6 (least important)

Rank the items below, using numeric values starting with 1 .

Teach awareness of technological innovations

Teach students how databases in general are structured

Teach students how to find information in various sources

Teach students how to locate materials in the library

Teach students how to critically evaluate the quality and usefulness of information

Teach students general research strategies

Teach students how to manage information

Other, please state (include ranking) 


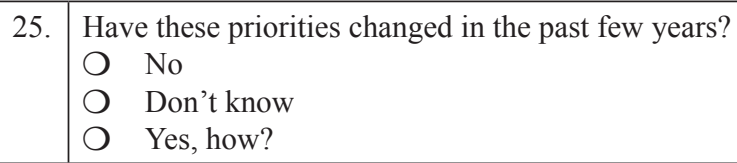

26. How would you like to see the objectives (written or not) of your instruction change? Please rank from 1 (should be most important) to 6 (should be least important) Rank the items below, using numeric values starting with 1. Teach awareness of technological innovations Teach students how databases in general are structured Teach students how to find information in various sources Teach students how to locate materials in the library Teach students how to critically evaluate the quality and usefulness of information Teach students general research strategies Teach students how to manage information Other, please state (with rank)

27. Which of the following would you include in your definition of "information literacy"? (Check all that apply)

$\bigcirc$ Recognizing when information is needed

Understanding how information is generated, organized, stored, and transmitted

Understanding some ethical, legal, economic, and sociopolitical information issues

Understanding that there exists a wide variety of information sources beyond the obvious

Understanding how to efficiently and effectively locate information from many sources

Understanding how to efficiently and effectively use information from many sources

Understanding how to critically analyze and evaluate information

Knowing how to think critically in general

Other, please specify

28. For questions 28-36 please answer the following question(s): What should be the degree of responsibility of academic librarians in teaching the following? If the responsibility is shared, please explain who else is responsible.

Recognizing when information is needed:

O Not responsible

Partially responsible

Fully responsible

Who else should be responsible?

29. Understanding how information is generated, organized, stored, and transmitted:

Not responsible

Partially responsible

$\bigcirc$ Fully responsible

Who else should be responsible?

30. Understanding some ethical, legal, economic and sociopolitical information issues:

Not responsible

Partially responsible

Fully responsible

Who else should be responsible?

31. Understanding that there exists a wide variety of information sources beyond the obvious:

Not responsible

Partially responsible

$\bigcirc$ Fully responsible

Who else should be responsible? 


\begin{tabular}{|c|c|}
\hline 32. & $\begin{array}{l}\text { Understanding how to efficiently and effectively locate information from many } \\
\text { sources: } \\
\text { Not responsible } \\
\text { Partially responsible } \\
\text { Fully responsible } \\
\text { Who else should be responsible? }\end{array}$ \\
\hline 33. & $\begin{array}{l}\text { Understanding how to efficiently and effectively use information from many sources: } \\
\text { Not responsible } \\
\text { Partially responsible } \\
\text { Fully responsible } \\
\text { Who else should be responsible? }\end{array}$ \\
\hline 34. & $\begin{array}{l}\text { Understanding how to critically analyze and evaluate information: } \\
\text { Not responsible } \\
\text { Partially responsible } \\
\text { Fully responsible } \\
\text { Who else should be responsible? }\end{array}$ \\
\hline 35. & $\begin{array}{l}\text { Knowing how to think critically in general: } \\
\text { Not responsible } \\
\text { Partially responsible } \\
\text { Fully responsible } \\
\text { Who else should be responsible? }\end{array}$ \\
\hline 36. & $\begin{array}{l}\text { Other? } \\
\text { Not responsible } \\
\text { Partially responsible } \\
\text { Fully responsible } \\
\text { Who else should be responsible? }\end{array}$ \\
\hline 37. & $\begin{array}{l}\text { To what extent is your instruction informed by the new ACRL Framework for } \\
\text { Information Literacy for Higher Education? } \\
\text { The Framework does not inform my instruction at all } \\
\text { The Framework has had minor influence on my instruction } \\
\text { The Framework has had a significant influence on my instruction } \\
\text { Please comment }\end{array}$ \\
\hline 38. & $\begin{array}{l}\text { Do you believe that your library effectively meets its current teaching objectives? } \\
\text { Yes } \\
\text { No } \\
\text { Don't know }\end{array}$ \\
\hline 39. & $\begin{array}{l}\text { How do you assess student learning in your instruction program? (Check all that } \\
\text { apply) } \\
\text { We do no assessments } \\
\text { Through student self-assessment } \\
\text { By comparing pre- and post-instruction test results } \\
\text { Through formative assessment during in-class sessions } \\
\text { Through quizzes/tests } \\
\text { Through information literacy assignments } \\
\text { Through questions and activities integrated into course assignments and exams } \\
\text { Through citation analysis of course assignments } \\
\text { Faculty feedback } \\
\text { Other, please specify }\end{array}$ \\
\hline
\end{tabular}


40. How do you evaluate the effectiveness of your library's instruction program? (Check all that apply)

O We do no evaluations

O Self-evaluation by individual instructors/librarians

Informally from feedback received from faculty

Informally from feedback received from students

B By reviewing student learning assessment results

With feedback questionnaires to faculty

With feedback questionnaires to students

Through citation analysis of course assignments

Other, please specify

41. Is instruction in your library provided with distinct funding in the library budget?

O No

Don't know

Yes - what proportion of the budget is dedicated to instruction?

42. How much nonfinancial support (e.g., administrative support, recognition, encouragement) does your library administration provide for instructional activities?

$\bigcirc$ Full support

Moderate support

Very little support

No support

43. How do you publicize instructional programs in your library? (Check all that apply)

Personal faculty contact

Notices or letters to faculty

Notices in campus newspaper

Notices on web

P Posters

Email discussion lists

Departmental meetings

O Social media

We do not purposefully promote instruction in our library

Other, please specify

44. What are some of the challenges you face as you try to provide instruction?

45. Do you have any other comments about instruction at your campus?

This concludes the survey. Thank you for your participation. 


\section{Notes}

1. "Framework for Information Literacy for Higher Education," Association of College \& Research Libraries (ACRL), 2015, available online at www.ala.org/acrl/standards/ilframework [accessed 24 June 2016].

2. Melissa L. Gold and Margaret G. Grotti, "Do Job Advertisements Reflect ACRL's Standards for Proficiencies for Instruction Librarians and Coordinators? A Content Analysis," Journal of Academic Librarianship 39, no. 6 (2013): 558-65.

3. Melissa Gross and Don Latham, "What's Skill Got to Do with It? Information Literacy Skills and Self-views of Ability among First-year College Students," Journal of the American Society for Information Science and Technology 63, no. 3 (2012): 574-83.

4. "Framework for Information Literacy for Higher Education."

5. Heidi Julien and Gloria J. Leckie, “Bibliographic Instruction Trends in Canadian Academic Libraries," Canadian Journal of Information and Library Science 22, no. 2 (July 1997): 1-15; Heidi Julien, "Information Literacy Instruction in Canadian Academic Libraries: Longitudinal Trends and International Comparisons," College and Research Libraries 61, no. 6 (Nov. 2000): 510-23; Heidi Julien, "A Longitudinal Analysis of Information Literacy Instruction in Canadian Academic Libraries," Canadian Journal of Information and Library Science 29, no. 3 (2006): 289-313; Heidi Julien, Maria Tan, and Shannon Merillat, "Instruction for Information Literacy in Canadian Academic Libraries: A Longitudinal Analysis of Aims, Methods, and Success," Canadian Journal of Information and Library Science 37, no. 2 (2013): 81-102; Mugyabuso J. Lwehabura and Christine Stilwell, "Information Literacy in Tanzanian Universities: Challenges and Potential Opportunities," Journal of Librarianship and Information Science 40, no. 3 (2008): 179-91; Glenrose V. Jiyane and Omwoyo Bosire Onyancha, "Information Literacy Education and Instruction in Academic Libraries and US Schools in Institutions of Higher Education in South Africa," South African Journal of Library $\mathcal{E}$ Information Science 76, no. 1 (2010): 11-23; Claire McGuinness, "Information Skills Training Practices in Irish Higher Education," Aslib Proceedings 61, no. 3 (2009): 262-81; Vijay Pattar and Satish Kanamadi, "Content and Delivery Methods of Information Literacy Programmes in Academic Libraries: A Pilot Study," Information Studies 16, no. 2 (2010): 103-12.

6. "Framework for Information Literacy for Higher Education," 3.

7. Ibid., 2.

8. Nicole A. Cooke \& Merinda K. Hensley, "The Critical and Continuing Role of Library and Information Science Curriculum in the Teacher Training of Future Librarians," Information Research 18, no. 3 (2013), available online at www.informationr.net/ir/18-3/colis/paperS02.html\#. V3E0evkrJD8 [accessed 15 January 2017]; Yusuke Ishimura and Joan C. Bartlett, "Information Literacy Courses in LIS Schools: Emerging Perspectives for Future Education," Education for Information 27, no. 4 (2010): 197-216; Julien, Tan, and Merillat, "Instruction for Information Literacy," 81-102; C. Sproles, A.M. Johnson, and L. Farison, "What the Teachers Are Teaching: How MLIS Programs Are Preparing Academic Librarians for Instructional Roles," Journal of Education for Library and Information Science 49, no. 3 (2008): 195-209.

9. Julien and Leckie, "Bibliographic Instruction Trends,"1-15; Julien, "Information Literacy Instruction," 510-23; Julien, Tan, and Merillat, "Instruction for Information Literacy," 81-102.

10. "Framework for Information Literacy for Higher Education."

11. Heidi Julien, "Content Analysis," in SAGE Encyclopedia of Qualitative Research Methods, ed. L. Given (Los Angeles, Calif.: Sage, 2008), 120-22.

12. "Framework for Information Literacy for Higher Education."

13. Ibid.

14. Julien and Leckie, "Bibliographic Instruction Trends," 1-15; Julien, "Information Literacy Instruction," 510-23; Julien, "A Longitudinal Analysis," 289-313; Julien, Tan, and Merillat, "Instruction for Information Literacy," 81-102.

15. Julien, Tan, and Merillat, "Instruction for Information Literacy," 81-102.

16. Heidi Julien and Shelagh K. Genuis, "Emotional Labour in Librarians' Instructional Work," Journal of Documentation 65, no. 6 (2009): 926-37; Heidi Julien and Jen L. Pecoskie, "Librarians' Experiences of the Teaching Role: Grounded in Campus Relationships," Library \& Information Science Research 31 (2009): 149-54; Miriam L. Matteson, Sharon Chittock, and David Mease, "In Their Own Words: Stories of Emotional Labor from the Library Workforce," Library Quarterly 85, no. 1 (2015): 85-105. 